Krzysztof RADZIUN, Lucjan TOMASIK

\title{
ULTRASTRUCTURE OF HUCHO HUCHO (L.) SPERMATOZOA
}

\section{ULTRASTRUKTURA PLEMNIKÓW GLOWACICY HUCHO HUCHO (L.)}

\author{
Institute of Ichthyology \\ Szczecin
}

\begin{abstract}
Ultrastructural studies (TEM) on Hucho hucho (L.) spermatozoa revealed lack of acrosome and eccentric situation of the flagella in relation to the head and the middle piece. The relatively small middle piece, with characteristic mitochondrial collar, is separated from the flagella by a cytoplasmic canal. Axial part of the flagella is formed by a microtubular complex, of the formula 9+2. Apart from different size of various elements, ultrastructure of Hucho hucho spermatozoa is similar to that in other salmonids.
\end{abstract}

\section{INTRODUCTION}

Morphology of spermatozoa has been studied in most Salmonidae species, both with optic microscopy (Leydig 1857, His 1873, Miescher 1878, Blanc 1894, Retzius 1905, Ballowitz 1915a,b) and taking advantage of phase contrast, and since the begining of the fifties - also with electron transmission or scanning microscopes (Rötheli and Roth 1950, Rötheli et al. 1950, Fischer et al. 1952, Yamamoto 1952, Hug et al. 1953, Lowman 1953, Geiger 1955, Furieri 1962, Billard 1970, Nicander 1970, Zirkin 1975, Fribourgh and Soloff 1976, Fribourgh 1978, Drozdov et al. 1981). So far, there have been, however, no detailed morphological studies on Hucho hucho (L.) spermatozoa. 


\section{MATERIAL AND METHODS}

Material for ultrastructural studies consisted of spermatozoa obtained during artificial stripping of mature Hucho hucho males (at the age of 4+) in the Polish Anglers, Association Station at Eopuszna. This fish species occurs in Poland only in the Czarna Orawa River and its tributaries (autochthonous Hucho hucho), in rivers Dunajec and Poprad, and probably also in the Scinawa (introduced Hucho hucho) (Witkowski and Kowalewski 1980). Ejaculates were collected and transported in cooled thermos flasks to Szczecin (about $24 \mathrm{~h}$ ).

The spermatozoa were fixed in $3 \%$ glutaraldehyde in $0.1 \mathrm{M}$ sodium cacodylate buffer, at $4{ }^{\circ} \mathrm{C}$ for 24 hours. For "shadow" analysis, preserved spermatozoa in form of a suspension were transferred onto nets covered with a Formvar film, and "positive" stained with $1 \%$ aquatic solution of uranyl acetate. The material for thin sections was postfixed in $1 \%$ solution of osmium tetroxide in $0.1 \mathrm{M}$ cacodylate buffer for 1 hour, dehydrated in the acetone series, and immersed in vestopal W. Ultrathin sections, obtained with a Tesla BS 490 A ultramicrotom, were stained with uranyl acetate and lead citrate, according to Reynolds (1963). The sections were examined and photographed under a $242 \mathrm{E}$ Tesla transmission electron microscope (TEM) at acceleration voltage of $60 \mathrm{KV}$.

The obtained ejaculate was clear, of uniform texture. It was easily evacuated when compressed. Quality parameters of the sperm, determined immediately after fish stripping, were as follows: spermatozoa motility (obtained with the method by Tomasik, 1973) at water temperature of $\pm 6^{\circ} \mathrm{C}$ and $1 / 100$ sperm dilution $-48 \mathrm{~s}$, out of which progressive movement took $9 \mathrm{~s}$, and the pendular movement took $39 \mathrm{~s}$; per cent of activated spermatozoa - 100; spermatocrit (determined with the method by Winnicki and Tomasik, 1976) - 11\%. All the above values represent means of three measurements.

\section{GENERAL MORPHOLOGY}

A Hucho hucho spermatozoon, similarly to that of other fish species, is a thread-like form, about $30 \mu \mathrm{m}$ long, in which 3 parts can be distinguished: head, middle piece and flagella (Figs 1 and 2). The head is oval in shape, $2.5 \mu \mathrm{m}$ long, slightly flattened laterally, with the diameter of 1.28 to $2.0 \mu \mathrm{m}$ (1.74 $\mu \mathrm{m}$ on the average). There is no acrosome, and the back part contains an implantation cavity, about $0.85 \mu \mathrm{m}$ deep, housing the frontal part of the flagella. Lack of acrosome is a characteristic feature of all Teleostei (Ginsburg 1963a,b, 1968). Lack of acrosome in salmonid species was already revealed by Ballowitz (1915a) in his cytological studies and confirmed by electron microscopy studies of Fischer et al. (1952), Lowman (1953), Furieri (1962), Billard (1970), Koehler (1970), Fribourgh and Soloff (1976), Fribourgh (1978), Stein and Imanabadi (1979), Drozdov et al (1981). 

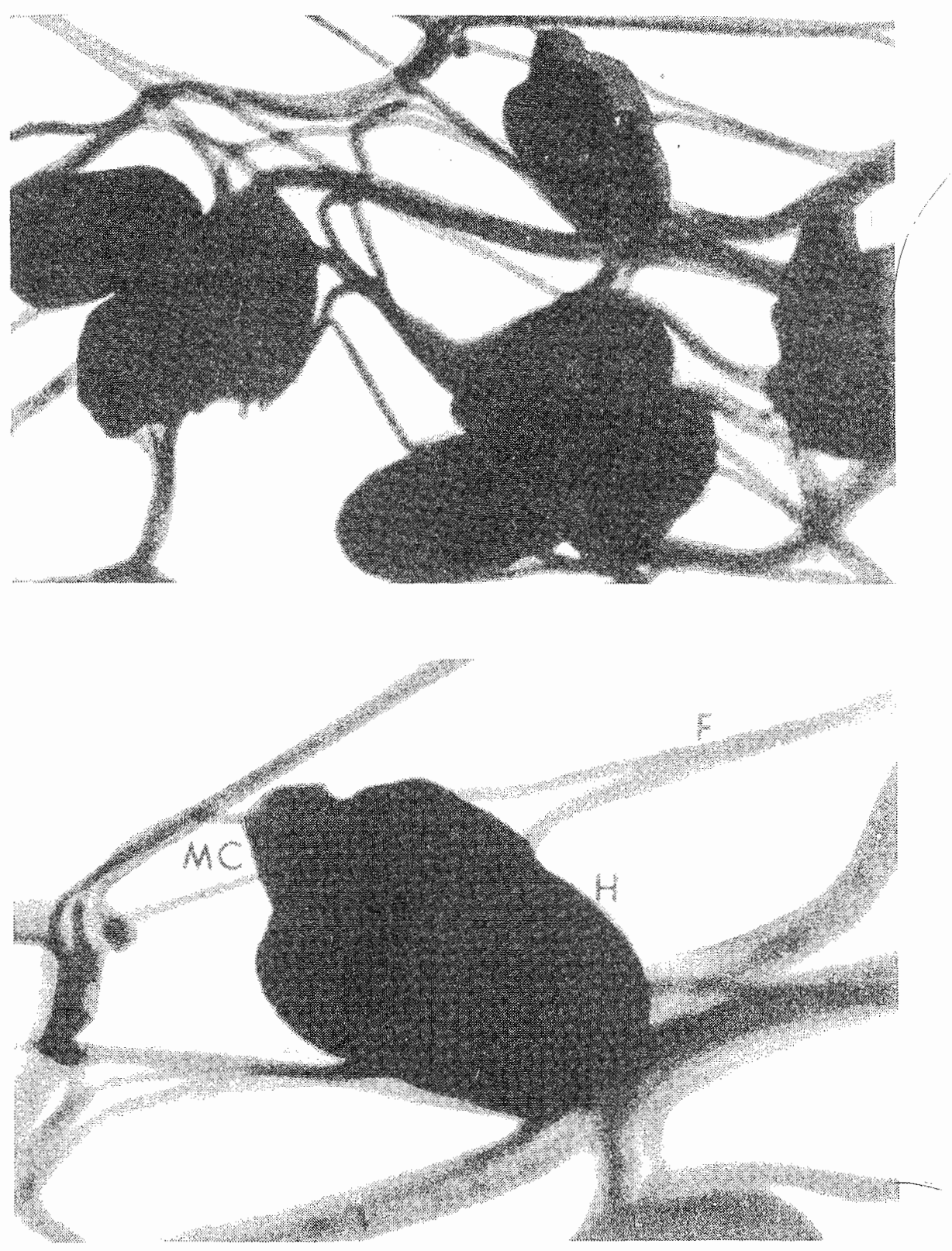

Fig. 1, 2. Shadowed elektronograms of Hucho hucho spermatozoa stained "positively" with uranyl ace tate: F - flagella; $\mathrm{H}$ - head; MC - mitochondrial collar. $1-8000 \mathrm{x}, 2-18000 \mathrm{x}$. 


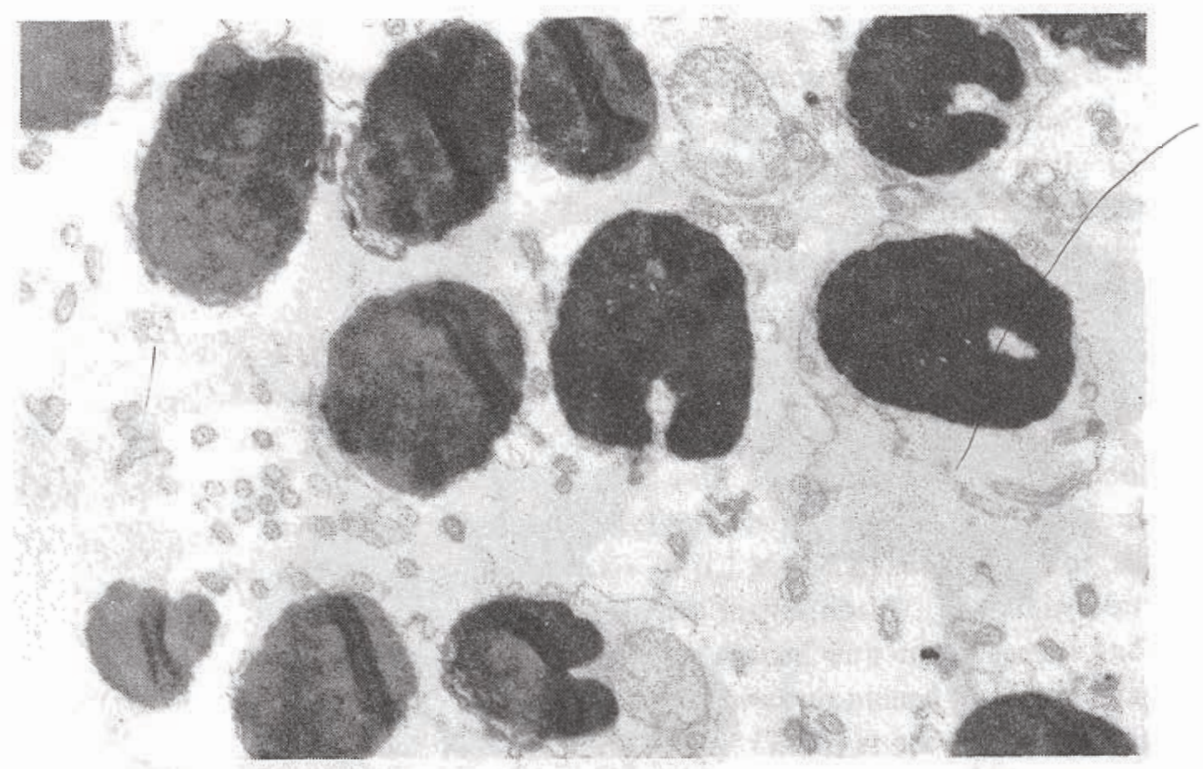

Fig. 3. Part of a scrap with oblique-transverse sections of Hucho hucho spermatozoa. $10300 \mathrm{x}$.

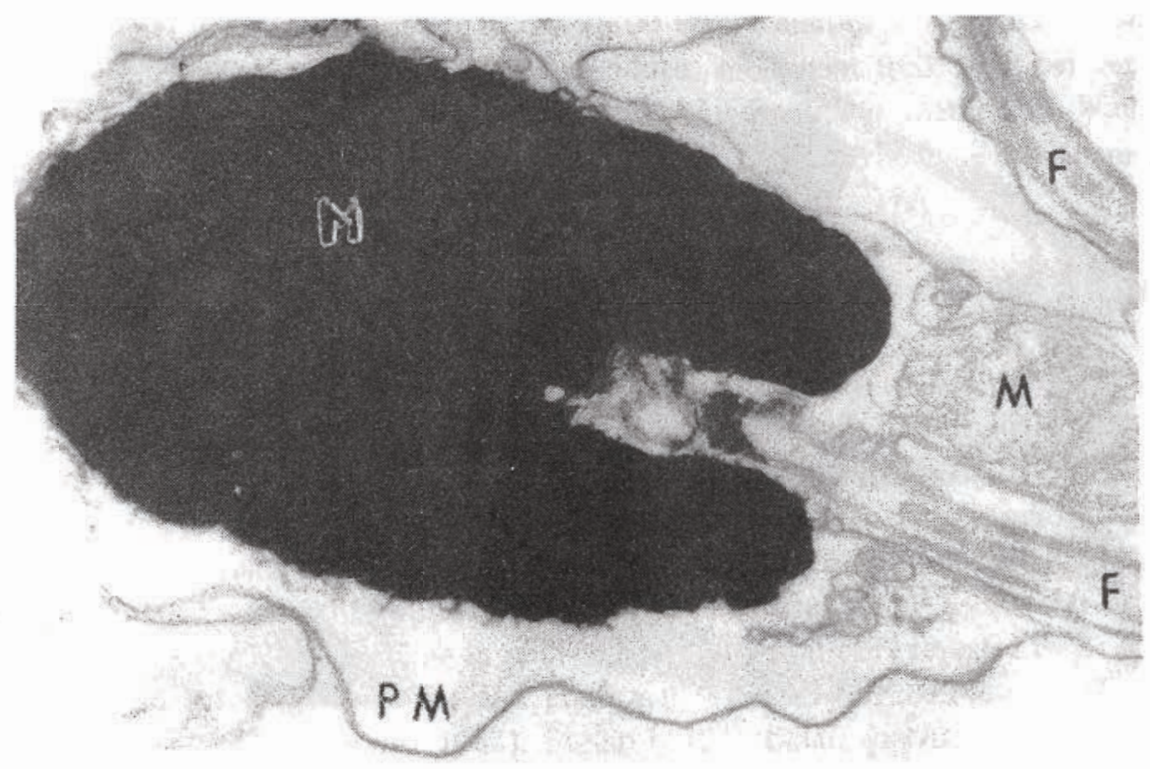

Fig. 4. Longitudinal section of the front part of a spermatozoon: F - flagella; $M$ - mitochondria; $N$ nucleus; PM - plasmatic membrane. $37000 \mathrm{x}$. 
The short middle piece, incorrectly - with regard to fish spermatozoa-called "neck", contains a single mitochondria, in form of a mitochondrial collar, about $0.9 \mu \mathrm{m}$ long, and $1.3 \mu \mathrm{m}$ diameter (Figs 2,3). The collar surrounds, not very tightly, the flagella base, as shown in Fig. 7 and 8 a.

It seems that a similar pattern of an incomplete flagella base cover by the mitochondrial collar is present also in the rainbow trout (Fribourgh and Soloff, 1976).

The terminal, longest part of a spermatozoon, i.e. flagella, is about $26 \mu \mathrm{m}$ long (it was not possible to find a spermatozoon with ideally stretched flagella, so the length given is an approximate one). Its breadth (without lateral ridges), measured behind the mitochondrial collar and before the end, was $0.17 \mu \mathrm{m}$ on the average. The flagella is situated eccentrically in relation to the head and the middle piece (Figs 4 and 6), which was observed also in other Salmonidae species (Yamamoto 1952, Lowman 1953, Ginsburg 1968). The flagella tapers with length. Sharp cytoplasmic ridges run on the sides of the flagella (Figs 9 and 10); they are also observed in spermatozoa of rainbow trout (Billard 1970, Fribourgh and Soloff 1976), brook trout (Billard 1970), Atlantic salmon (Nicander 1970), Oncorhynchus kisutch (Lowman 1953), brown trout (Fribourgh 1978) and Oncorhynchus gorbuscha (Drozdov et al. 1981).

\section{MICROSTRUCTURE}

The spermatozoon head is covered with the nuclear membrane, and the plasmolemma on the outside, the latter extending to cover the middle piece and the flagella. Nuclear part of the head is composed of chromatin substance, in the form of loosely packed granules in the front part of the head, and condensed at the back (Figs 5 and 6). A characteristic implantation cavity in the back part of the head can be seen in Figs 4, 6 and 7. It contains the front part of the middle piece of spermatozoon, with clearly visible centriole (proximal and distal) (Figs 4,6 and 7). The basal plate was also observed in front of the proximal centriole (Fig. 7).

In the region of mitochondrial collar, under the plasmolemma, cytoplasmic vesicles and a system of smooth cysterns and endoplasmic membranes were observed. Most probably, they were remains of spermiogenesis, and were defined as a rudimentary cytoplasm (Figs 7 and 8b). The single collar-like mitochondria in the high-energy orthodox configuration contained mitochondrial crests. The middle piece together with the head was separated from the flagella by a circuitous cytoplasmic canal (formed through the cytoplasmic membrane invagination, as shown in Figs 7 and 8). This canal occurs frequently in fishes in which external fertilization takes place (Nicander 1970, Fribourgh and Soloff 1976, Brusle 1981).

The flagella is composed of axial filaments, extending from the distal centriole in the middle piece. It is surrounded with a layer of the cytoplasm, and covered with a cytoplasmic film. Its axial part consists of a microtubular complex, similarly as in other Teleostei (Bacetti and Afzelius 1976), of the formula 9+2, i.e. two single central 


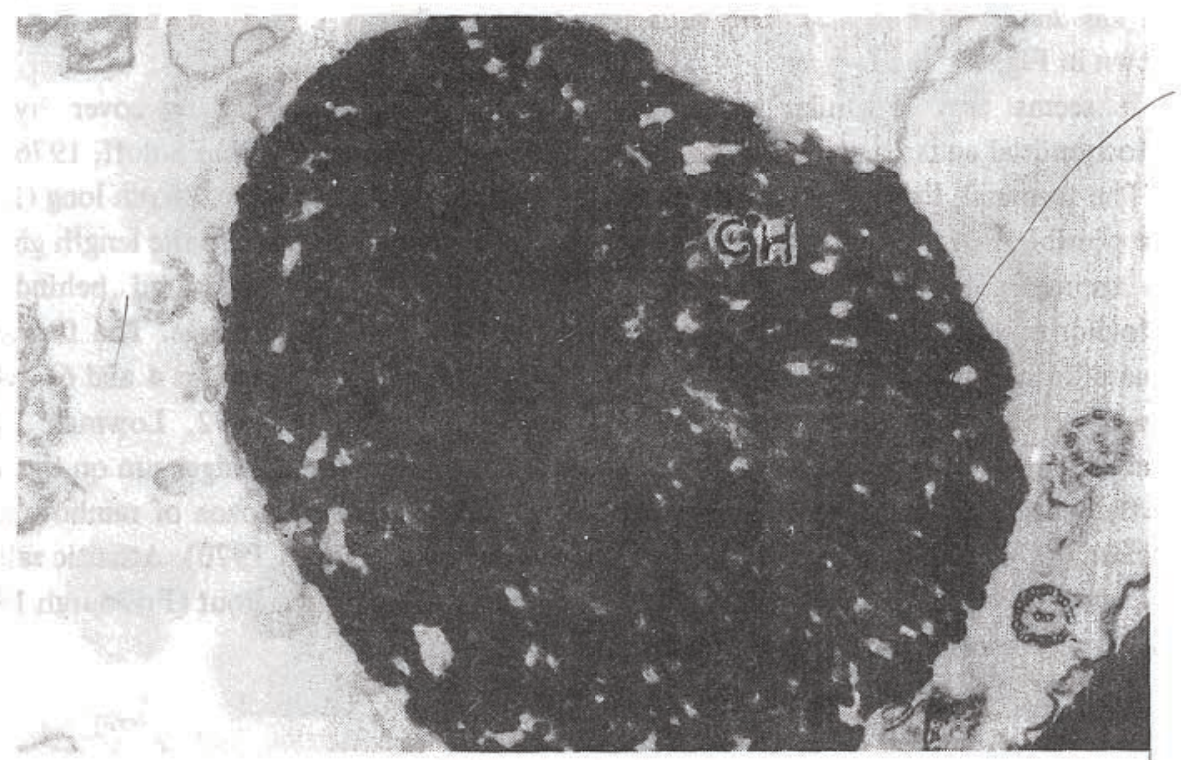

Fig. 5. Ultrastructure of the front part of spermatozoon head. Longitudinal section with loosely packed chromatin granules: $\mathrm{CH}-$ chromatin. $38000 \mathrm{x}$.

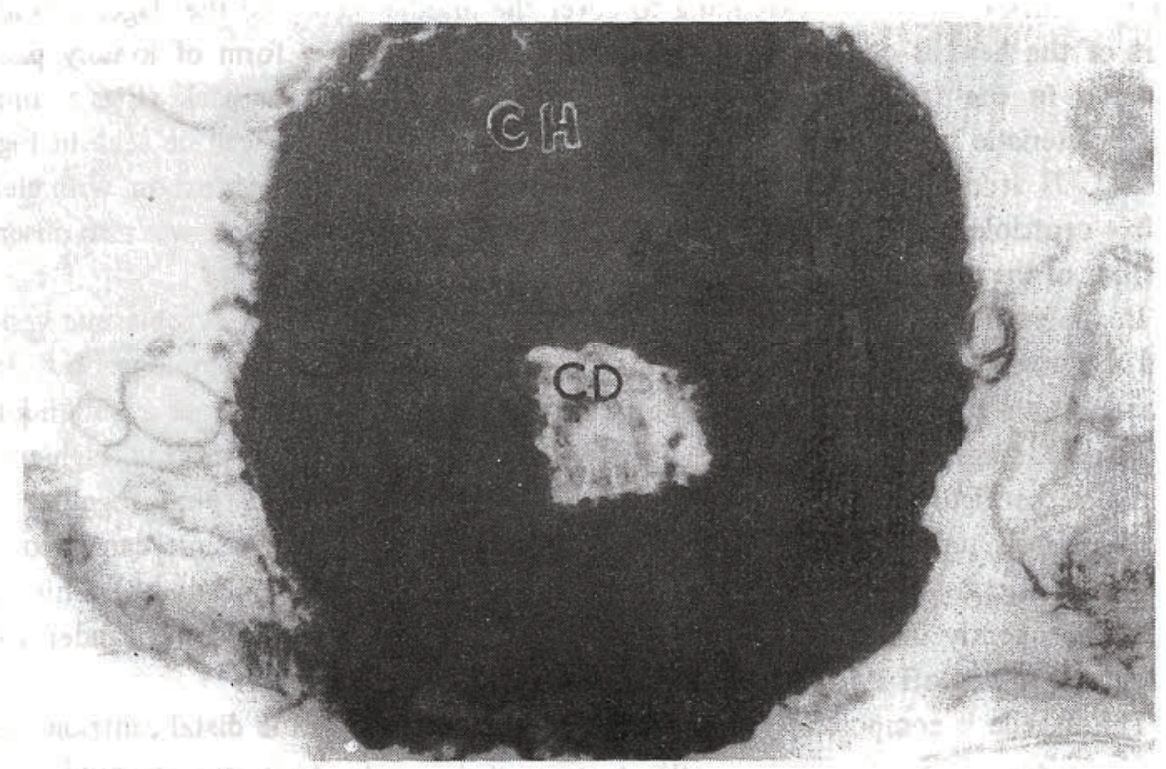

Fig. 6. Cross-section of the back part of spermatozoon head, at the level of implanted cavity. Distal centriole and chromatin in a condensed form well visible. CD - distal centriole. $53400 \mathrm{x}$. 


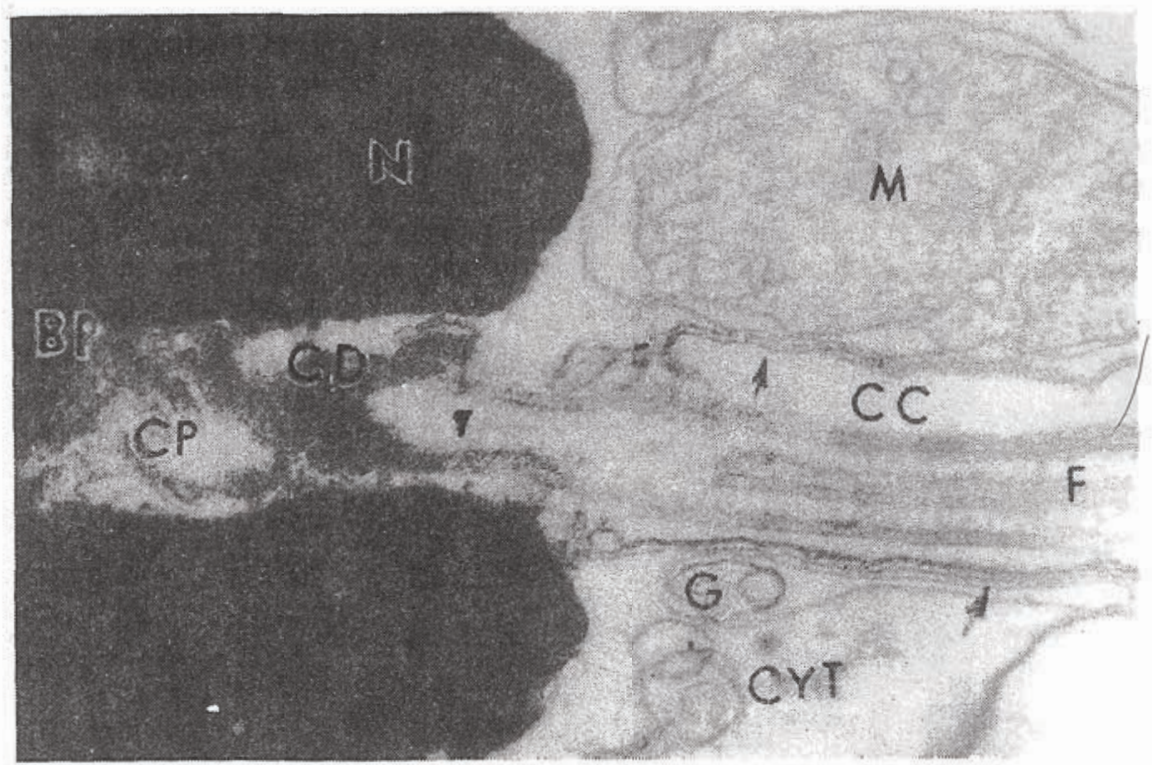

Fig. 7. Ultrastructure of the middle piece of a spermatozoon. Longitudinal section. BP - basal plate; CC - cytoplasmic canal; CP - proximal centriole; CYT - rudimentary cytoplasm; G - flat endoplasmatic cistern; $\mathrm{N}$ - nucleus; $\mathrm{V}$ - transition region; $\downarrow \downarrow \downarrow$-cy toplasmic condensation.
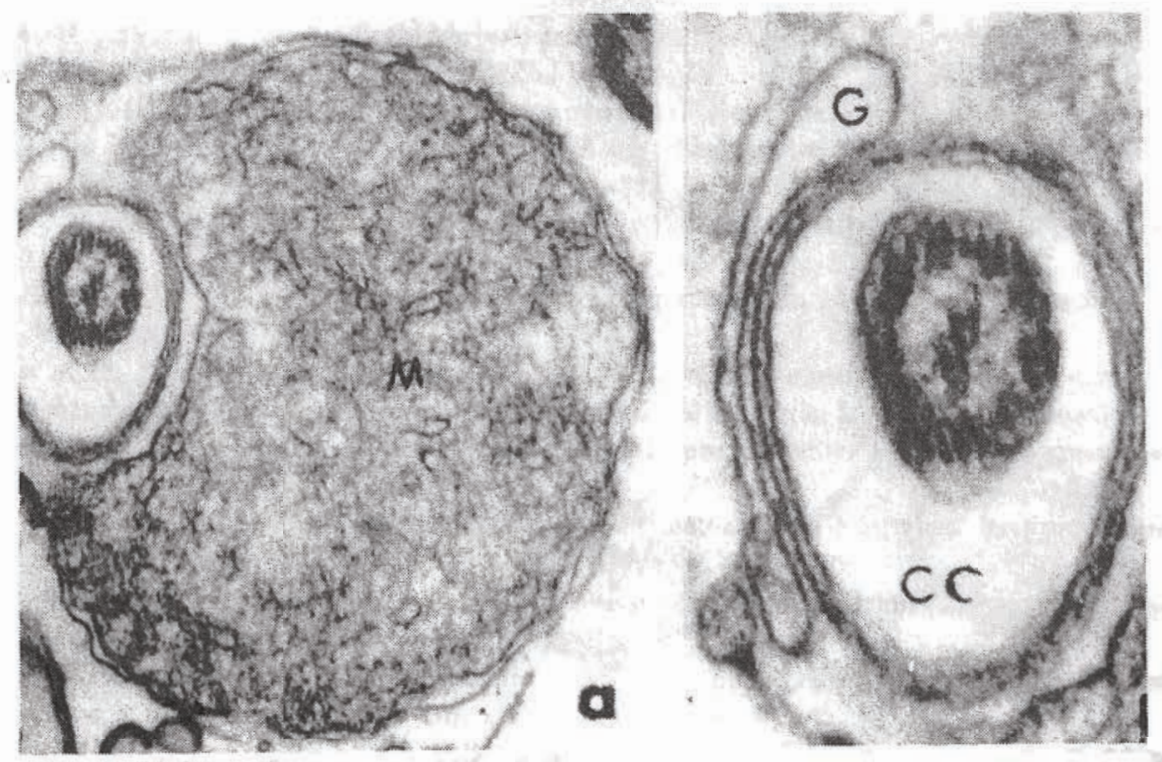

Fig. 8. Cross-section of the middle piece of a Hucho hucho, spermatozoon.

Denotations as in Fig. 7. A - $55000 \mathrm{x}, \mathrm{B}-118000 \mathrm{x}$. 


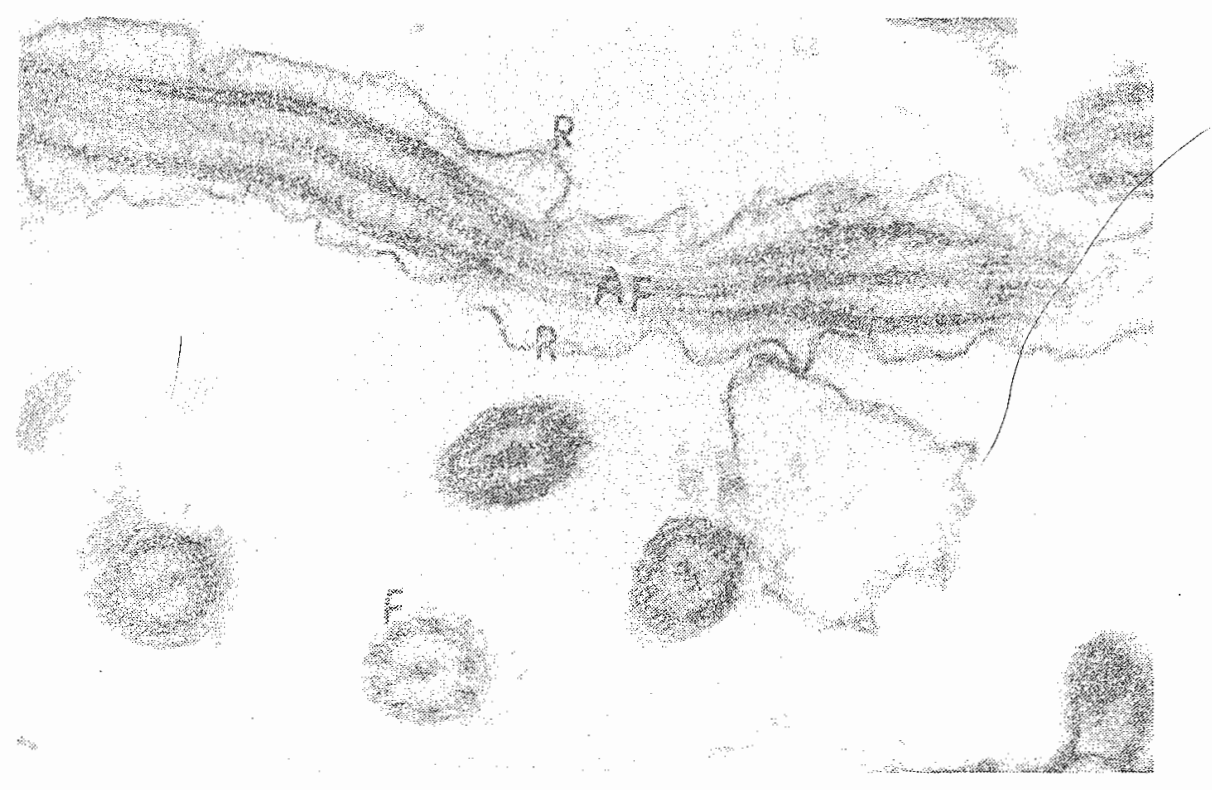

Fig. 9. Longitudinal section of a flagella with visible folds of the cytoplasmic membrane. AF - axial filaments; $\mathrm{R}$ - ridge. $72000 \mathrm{x}$.
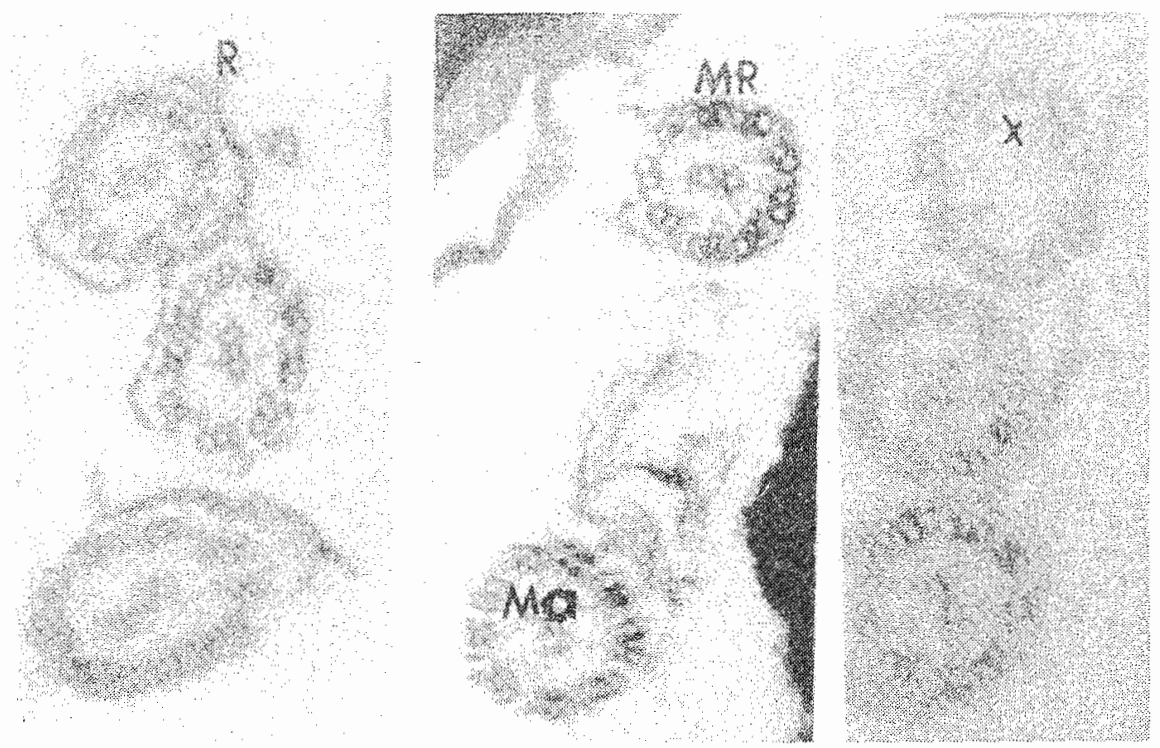

Fig. 10. Cross-sections of flagella with axial microtubules (MO), and circular microtubules (MR) of the formula $9+2$, with visible ridges of cytoplasmic membranes $(R)$, and terminal part of flagella $(*)$ without axial microtubules, of the formula $9+0$. About $100000 \mathrm{x}$. 
microtubules surrounded ringlike by 9 double microtubules (Figs 7,9 and 10). Peripheral and axial microtubules seem to be interconnected by straight filaments, which was also observed in crucian carp by Fribourgh et al. (1970). Each of the 9 double peripheral microtubules is composed of a cylindric microtubule $A$, and an adjacent incomplete cylinder of microtubule $\mathbb{B}$. Microtubule $A$ contains two arms (internal and external), directed toward microtubule $\mathbb{B}$ of the adjacent pair (Fig. 10). The presence of similar arms was observed by $B$ illard (1970) in rainbow and brown trout spermatozoa, and by Fribourgh et al. (1970) in crucian carp. Additionally, peripheral tubules are connected by means of 9 radial spokes/with an envelope which surrounds the pair of axial tubulés (Fig. 10). These radial spokes seem to extend from tubules $\mathbb{A}$ (as observed by Fribourgh et al., 1970, in crucian carp).

Hence, the structure of Hucho hucho spermatozoa does not deviate in any significant way from that observed in other salmonids, the only differences being those regarding the size of various parts.

Translated: Dr Teresa Radziejewska

\section{REFERENCES}

BaccettiB., Afzelius B., 1976: The biology of the sperm cell (Monographs in developmental biology, v. 10), S. Karger, A. Ges. Basel.

Balliowitz $\mathbb{E} ., 1915 \mathrm{a}$ : Über die Samenkörper der Forellen.-Arch. Zellforsch., 14:185-192.

Ballowitz $\mathbb{E}$ 。, 1915b: Über die Samenkörper des Lachses. Ein weiterer Beitrag zur Kenntnis der Spermien der Salmoniden.-Arch. Zellforsch., 14: 451-463.

$\mathbb{B}$ illard $\mathbb{R}_{\circ}$, 1970: Ultrastructure comparée de spermatozoides de quelques poissons teleostéens. Proc. I Intern. Symposium in Rome and Siena, 1969. In: "Comparative Spermatology (ed. B. Baccettii)". Academic Press, New York - London: 71-79.

Blanc $\mathbb{H}_{\text {. }}$ 1894: Étude sur la fecondation de l'oeuf de la Truite. Ber. Naturforsch. Ges., Freiburg, 8: 163-191.

Brusle S., 1981: Ultrastructure of spermiogenesis in Liza aurata Risso, 1810 (Teleostei, Mugilidae).Cell Tissue Res., 217: 415-424.

Drozdov A.L., Kolotuchina N.K., Maksimovi A.A., 1981: Osobiennosti gistologiCeskogo stroenija semennikov i ultrastruktura spermatozoidov gorbuß̌i. - Biol. moria, 1: 49-53. (in Russian).

Fischer H., Hug O., Lippert W., 1952: Elektronenmikroskopische Studien an Forellenspermatozoen und ihren Zellkernen.-Chromosoma, 5: 69-80.

Fribourgh J,. 1978: Morphology of the brook trout spermatozoon as determined by scanning and transmission electron microscopy.- Progr. Fish Culturist, 40: 26-29.

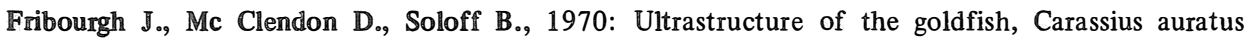
(Cyprinidae) spermatozoon.-Copeia 2: 274-279.

Fribourgh J., Soloff B., 1976: Scanning electron microscopy of the rainbow trout (Salmo gairdneri Richardson) spermatozoon.- Arkansas Acad. Sci. Proc., 30: 41-43.

Furieri Po, 1962: Prime osservazioni al microscopic elettronico sullo spermatozoo di Salmo trutta L. - Bolletino Soc. Ital. Biol. Speriment., 20, 428; 1030-1032.

Geiger W., 1955: Elektronenoptische Untersuchungen am Salmonidensperma Rev. Suisse Zool., 62: $325-334$. 
Ginsburg A.S., 1963a: Soedinenije gameł bez aktivacii jajca u łososevych ryb. Ž. obł̌č. biol., 24 106-119 (in Russian).

Ginsburg A.S., 1963b: Sperm-egg association and its relationship to the activation of the egg in Salmonid fishes. - J. Embryol. exp. morph., 11, pt 1: 13-33.

Ginsburg A.S., 1968: Oplodotvorenije u ryb i problema polispermii. M., Izd. 'Nauka" (in Russian)

His W., 1873: Untersuchungen über das Ei und die Entwicklung bei Knochenfischen. Leipzig.

Hug O., Lippert W., Fischer H., 1953; Das elektroenoptische Bild der Salmonidenspermatozoen.Protoplasma, 42: 94-99.

Koehler J., 1970: Freeze-etching studies on spermatozoa with particular reference to nuclear and post-nuclear cap structure.-Proc. I Intern. Symposium in Rome and Siena, 1969. In: "Comparative spermatology (ed. B. Baccetti)". Academic Press, New/York - London; $515--522$.

Leydig F., 1857: Lehrbuch der Histologie des Menschen und der Tiere. Hamm.

Lowman F., 1953: Electron microscope studies of silver salmon spermatozoa. (Oncorhynchus kisutch (Walbaum)). Exp. Cell Res. 5: 335-360.

Miescher F., 1878: Die Spermatozoen einiger Wirbeltiere. Ein Beitrag zur Histochemie:-Verhandl. Naturforsch. Ges. Basel. 6; 128.

Nicander L., 1970: Comparative studies of the fine structure of vertebrate spermatozoa. Proc. I Intern. Symposium in Rome and Siena, 1969. In: "Comparative spermatology (ed. B. Baccetti)". Academic Press. New York - London: 47-55.

Retzius G., 1905: Zur Kenntnis der Spermien der Leptokardier, Teleostier und Ganoiden.-Biol. Unt. N.F. 12: 103-115.

Reynolds E., 1963: The use of lead citrate at high $\mathrm{pH}$ as an electron opaque stain in electron microscopy.-J. Cell Biol., 17: 208-212.

Rötheli A., Roth Ho, 1950: Elektronenoptische Untersuchungen an Salmonidenspermien.-Rev。 suisse Zool., 57: 503-510.

Rötheli A., Roth H., Medem F., 1950: Elektronenoptische Untersuchungen der Strukturveränderung agglutinierter Fischspermien.-Exp. Cell Res., 1: 115-126.

Stein H., Imanabadi J., 1979: Spermaeigenschaften der Regenbogenforelle (Salmo gairdneri Richardson). - Bayer. Landw. Jb. 56: 681-689.

Tomasik L., 1973: Specific and individual differences in motility between salmonid spermatozoa. Acta Ichthyol. Pisc., 3, 1: 11-17.

Witkowski A., Kowalewski M., 1980: Aklimatyzacja i rozsiedlenie głowacicy w Polsce. [Acclimatisation and distribution of Hucho hucho in Poland] Gosp. Rybna, 32, Nr 1: 6-9.

Winnicki A., Tomasik L., 1976: "Spermatocrit" as method for biological evaluation of fish sperm.Acta Ichthyol. Pisc., 6, 2: 6-9.

Yamamoto K., 1952: Studies of fertilization in the dog-salmon, Oncorhynchus keta. I. The morphology of the normal fertilization.- J. Fac. Sci., Hokkaido Univ., Ser. 6, 11: 81-94.

Zirkin B.R., 1975: The ultrastructure of nuclear differentiation during spermiogenesis in the salmon.J. Ultrastruct. Res. 50: 174-184.

Krzysztof Radziun, Lucjan Tomasik

\section{ULTRASTRUKTURA PLEMNIKÓW GŁOWACICY HUCHO HUCHO L.}

\section{STRESZCZENIE}

Poddano analizie ultrastrukturalnej (TEM) plemniki głowacicy (Hucho hucho (L.)) uzyskane od samców z Ośrodka PZW w Łopusznej. Stwierdzono typową dla ryb łososiowatych budowę 
plemników, z charakterystycznym, nieco ekscentrycznym w stosunku do główki (długości 2,5 $\mu \mathrm{m}$ ) i części środkowej osadzeniem witki oraz brak akrosomu. Część środkowa, stosunkowo niewielka $(1,75 \mu \mathrm{m}) \mathrm{d} \nmid u g o s ́ c i), z$ kołnierzowato ukształtowanym pojedynczym mitochondrium oddzielonym od witki okrężnym kanałem cytoplazmatycznym, wkomponowana jest przednią częścią (tzw. wstawka) w charakterystyczne wgłębienie implantacyjne tylnego odcinka główki. Witka, najdłuższa część plemnika (około $26 \mu \mathrm{m}$ długości), posiada boczne fałdy cytoplazmatyczne. Osiową część witki tworzy, podobnie jak u większości Teleostei, kompleks mikrotubularny o formule $9+2$.

Родзюн Кө, Томасик Л.

УЛЬТРАСТРУКТУР А СЕРМАТОЗОИПОВ ПУНАЙСКОГО ЛОСО Ң Hucho hucho(L)

$P$ e 3 to $M$ e

Сперматозоиды дунайского лосося (Hucho hucho/ /L.). полученные от самцов, выращенных в Центре Польского Рыболовного Союза в Лопушной, подвергали ультраструктурному анализу . Обнаружили типич ное для лососевых рыб строение сперматозоидов с характерным, немного эксцентричным по отношению $к$ головке (длиной 2,5 нм) и к средней части расположением хвостика, а также отсутствием окросома. Средняя часть относительно невелика (длиной $\perp, 75 \mu \mathrm{m}$ ) с одиночным митохондриумом в фороме воротника, отделённым от хвостика окружным цитоплазматическим каналом, и встроена передней частью (тнз.вставка) в характерное имплантационное углубление заднего отрезка головки. Хвостик, самая длинная часть

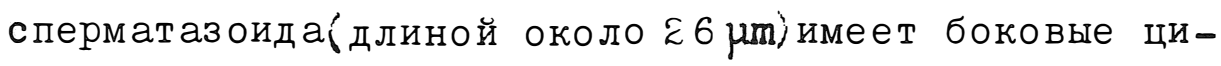
топлазматические складки. Осевую часть хвостика 
составляет, как и у большинства Teleosted, микротубулярный комплекс, согласно форомуле 9+2。

Authors' address:

Received 84.05 .04

Dr Lucjan Tomasik

Dr Krzysztof Radziun

Instytut I chtiologii

Wydziału Rybactwa Morskiego

Ul. Kazimierza Królewicza 4

Szczecin 71-550

Polska (Poland) 